\title{
Three Horses with severe respiratory distress like Adult Respiratory Distress Syndrome
}

\author{
Astrid Grosche', Alexandra Eckhoff und Gerald Fritz Schusser? \\ Medizinische Tierklinik der Veterinärmedizinischen Fakultät Leipzig ${ }^{1}$ and Department of Clinical Sciences, College of Veterinary Medicine, Kansas State University, \\ Manhattan, USA ${ }^{2}$
}

\begin{abstract}
Summary
The Adult Respiratory Distress Syndrome (ARDS) is a rare fatal disease in humans with a sudden interruption of the respiratory function characterized by non-cardiogenic pulmonary edema, alveolar epithelial injury, decreased surfactant, atelectasis and fibrosis. The objective of this study was to clarify the clinical and clinicopathologic findings of horses with severe respiratory distress such as ARDS, and to find out the optimal therapeutic approaches. In 2002 three horses with signs of acute respiratory failure, similar to those seen in ARDS, were examined at the Department of Large Animal Medicine. The typical clinical findings such as an acute onset of severe dyspnea and tachypnea (50-64 breaths/minute), therapy-resistant hypoxemia (arterial $\mathrm{pO}_{2}$ 4.6-7.2 $\mathrm{kPa}$ ) and an oxygen saturation of 53.9-87.9\% were the basis for the diagnosis. Based on the definition of the American-European Consensus Conference in 1994 human patients with ARDS require the presence of hypoxemia as manifested by a ratio of the partial arterial pressure of oxygen and the fraction of inspired oxygen $\left(\mathrm{PaO}_{2} / \mathrm{FlO}_{2}\right)<200 \mathrm{~mm}$ $\mathrm{Hg}$. In two cases the $\mathrm{PaO}_{2} / \mathrm{FlO}_{2}$ ratio was $<200 \mathrm{~mm} \mathrm{Hg}$ and in one case $200.4 \mathrm{~mm} \mathrm{Hg}$. Depending on the severity of the disease, also serum lactate and lactate dehydrogenase (LDH) were increased. Thoracic radiographs of one horse revealed the characteristic interstitial and alveolar infiltrates and pulmonary opacity with a normal cardiac silhovette. Only in one case an allergic small airway inflammation similar to those seen in acute onsets of recurrent airway obstruction could be determined as the basic cause of the disease. The cornerstone of therapy of ARDS in these horses was the continuous supplementation of oxygen. The application of the bronchodilator clenbuterol hydrochloride in a dosage of $2.4 \mu \mathrm{g} / \mathrm{kg}$ BW IV twice daily was found to be very effective in facilitating respiration in one horse. The administration of corticosteroids $(0.1 \mathrm{mg}$ dexamethasone/kg BM IV) deteriorated the dyspnea in two horses. These horses died 26 respectively 72 hours after admission. In conclusion human criteria for identification of ARDS may be helpful in diagnosis of ARDS in horses. Serum lactate and LDH could be of prognostic importance. The oxygen supply is the basis of treatment. Highly dosed bronchodilators appear to have a positive effect on the respiratory effort. The application of corticosteroids in the early stage of ARDS seems to worsen the dyspnea of horses.
\end{abstract}

Keywords: ARDS, horse, hypoxia, thoracic radiograph, oxygenation

\section{Hochgradige Atemnot bei drei Pferden: Ein Vergleich zum Adulten Respiratorischen Distress Syndrom}

Das Adulte Respiratorische Distress Syndrom (ARDS) ist eine seltene, lebensbedrohliche Erkrankung beim Menschen, die durch eine plötzliche Beeinträchtigung der Lungenfunktion hervorgerufen wird. Das ARDS ist durch ein nicht-kardiogenes Lungenödem mit Schädigung der Alveolarepithelien, Verminderung von Surfactant, Atelektase und Fibrose charakterisiert. In vorliegender Studie werden die klinischen und labormedizinischen Befunde von Pferden mit ARDS-ähnlichen Symptomen beschrieben und die Möglichkeiten einer optimalen Therapie diskutiert. Im Jahr 2002 wurden drei Pferde mit Symptomen einer akuten Atemnot vergleichbar mit denen eines ARDS in der Medizinischen Tierklinik vorgestellt. Dabei waren die typischen klinischen Befunde einer hochgradigen Dyspnoe und Tachypnoe (50-64 Atemzüge pro min), therapieresistenten Hypoxie (arterieller $\mathrm{pO}_{2}$ 4,6-7,2 kPa) und arteriellen Sauerstoffsättigung von 53,9-87,9 \% die Grundlage für die Diagnose. Für den Menschen wurde auf der American-European Consensus Konferenz 1994 das ARDS auf der Grundlage des Schweregrades der Hypoxie durch den Quotienten aus dem arteriellen Sauerstoffpartialdruck und der Sauerstoffkonzentration der Atemluft $\left(\mathrm{PaO}_{2} / \mathrm{FIO}_{2}\right)$ von $<200 \mathrm{~mm} \mathrm{Hg} \mathrm{definiert.} \mathrm{Bei}$ zwei Pferden lag $\mathrm{PaO}_{2} / \mathrm{FlO}_{2}<200 \mathrm{~mm} \mathrm{Hg}$ und bei einem Pferd bei 200,4 mm Hg. In Abhängigkeit vom Schweregrad der Erkrankung waren auch die Serum-Laktatkonzentration und die Laktatdehydrogenase erhöht. Die röntgenologische Untersuchung der Lungen ergab bei einem Pferd die charakteristischen interstitiellen und alveolären Infiltrate mit milchglasähnlicher Verschattung des Lungengewebes bei physiologischer Herzsilhovette. Nur in einem Fall konnte als Ursache des ARDS eine allergisch bedingte Alveolitis vergleichbar mit akuten Anfällen einer RAO eruiert werden. Ein Eckpfeiler der Behandlung stellte die kontinuierliche Saverstoffzufuhr dar. Die intravenöse Applikation von Clenbuterol in einer Dosierung von 2,4 $\mathrm{gg} / \mathrm{kg}$ KM i.v. zweimal täglich führte zu einer Verbesserung der Atemmechanik bei einem Pferd. Die parenterale Behandlung mit Kortikosteroiden (0,1 mg Dexamethason/kg KM i.v.) verschlechterte die Atemnot bei zwei Pferden. Diese beiden Pferde starben 26 bzw. 72 Stunden nach der Aufnahmeuntersuchung. Grundsätzlich sind die Diagnosekriterien eines ARDS des Menschen für die Beurteilung der Erkrankung beim Pferd hilfreich. Die Serumkonzentration von Laktat und die LDH-Aktivität könnten von prognostischer Bedeutung sein. Die Basis der Behandlung stellt auch beim Pferd die Sauerstoffapplikation dar. Bronchodilatatoren, hoch dosiert verabreicht, haben einen positiven Effekt auf die Atemarbeit. Die Applikation von Kortikosteroiden im Frühstadium der Erkrankung scheint die Symptome zu verschlechtern.

Schlüsselwörter: ARDS, Pferd, Hypoxie, Lungenröntgen, Beatmung

\section{Introduction}

The Adult Respiratory Distress Syndrome (ARDS) in humans, also known as shock lung, non-cardiogenic pulmonary edema or hyaline membrane disease, is a severe pulmonary injury characterized by an impairment of vascular permeability, pulmonary edema and decreased pulmonary compliance (Varon and Wenker 1997). The syndrome was first described in human beings, who showed an acute onset of progressive dyspnea, hypoxemia and panlobular alveolar infiltrates in thoracic radio- 
graphs (Ashbaugh et al. 1967). The clinical findings are similar to those of an acute respiratory distress in newborns (Riemensberger 2002). Generally, two major categories of risk have been characterized in humans: direct injury of alveolar function, such as pulmonary infection, aspiration, toxic inhalations, or indirect injury of alveolar function, such as severe organ injuries, septicemia or severe trauma (Petty 1985, Bernard et al. 1994, Lazarov et al. 2001). ARDS is the end result of an aggressive inflammatory process. The starting point of this uncontrolled activation of inflammatory cascades appears to be reactive oxygen radicals (Rinaldo and Christman 1998, Lang et al. 2002). There is an increased leucocyte production, and a rapid recruitment to the inflamed site. The neutrophil is the dominant leucocyte, wich causes cell damage through production of free radicals, cytokines including TNF, IL-1, IL-6, IL8 and proteases (Corrin 2000, Weiland et al. 1986, Welty-Wolf et al. 2002). A capillary endothelial and alveolar epithelial cell injury as a response of the neutrophil activation is initiated (Groeneveld 2003). The pathologic hallmark of these processes is diffuse alveolar damage. Histologically, the accumulation of hyaline membrane formation within the alveoli (exudative stage) compromising the vascular barrier integrity are characteristic findings (Corrin 2000). Subsequently, a replacement of damaged epithelial cells and accumulation of mesenchymal cells and connective tissue products in the alveolar space (fibroproliferative stage) take place (Corrin 2000). Clinical differentiation between the acute lung injury or pneumonia is difficult. The American-European Consensus Conference in 1994 proposed an operational definition for ARDS that requires the presence of hypoxemia as manifested by a ratio of the partial arterial pressure of oxygen and the fraction of inspired oxygen $(\mathrm{PaO} 2 / \mathrm{FIO} 2)<200 \mathrm{~mm} \mathrm{Hg}$ (Bernard et al. 1994). The management of affected patients is predominantly one of support and involves mainly the improvement of oxygenation and circulation (Udobi et al. 2003). The mortally rate associated with ARDS in humans is $20-70 \%$ and depends on the cause and timely emergency therapy (Bernard et al. 1994). In veterinary medicine, ARDS is not well recognized. Most reports describe clinical signs of respiratory distress in small animals (Wilkens and Seahorn 2004). Some studies reported pulmonary edema of non-cardiogenic origin in horses (Kelly et al. 1995, Lakritz et al. 1993, Turk et al. 1981). In neonatal foals the respiratory distress is most similar to the respiratory distress syndrome in human premature infants, where primary surfactant deficiency is an important part of the pathogenesis (Wilkens and Seahorn 2004). In foals between 1 and 7 months old signs of acute respiratory distress are often a result of bacterial or viral infection characterized by marked tachypnea, cyanosis unresponsive to nasal oxygen and pyrexia. The characteristically histopathologic pulmonary lesions included bronchiolitis and bronchointerstitial pneumonia. Type II cell hyperplasia and hyaline membrane formation were observed (Lakritz et al. 1993). Clinical findings of adult horses with acute respiratory distress reported in one study were similar o those of the foals described before. Histological examination of the lungs revealed diffuse alveolar damage with hyaline membrane formation, alveolar epithelialisation and alveolar septal fibrosis seen in ARDS of humans (Kelly et al. 1995).

This report describes the detailed clinical findings and diagnostic possibilities in adult horses with ARDS-like signs and the therapeutic approach based on three clinical cases seen at the hospital.

\section{Procedures}

In this study three horses with signs of acute respiratory distress were examined at the Department of Large Animal Medicine. The first horse (horse 1) admitted in January 2002 was a 5-year-old warmblood mare with a history of progressive respiratory distress and lethargy of three weeks duration. The horse was kept in a straw stall, received good-quality hay and oat and was regularly exercised. In March 2002, a 9year-old pony gelding (horse 2) with a three week-history of similar signs was referred. This horse had been pastured alone in a small grass paddock. In these two horses a routine deworming and vaccination against influenza and herpes virus infection were performed annually. In both cases a sudden deterioration with severe tachypnea, depression, and fever occurred before they were referred to the clinic. The third case was a 5-year-old pony gelding (horse 3) with severe acute respiratory distress observed after feeding on mouldy hay. The horse was kept in a straw stall with daily access to pasture. Deworming and vaccination were performed biannually. The clinical signs of these horses deteriorated despite of treatment with antibiotics, nonsteroidal antiphlogistics and bronchodilators.

Upon arrival, the physical examination and clinicopathologic evaluation of venous and arterial blood samples were performed. Clinicopathologic data included erythron', leukon', serum clinical chemistry ${ }^{2}$ and arterial blood gas ${ }^{3}$. The $\mathrm{PaO}_{2} / \mathrm{FIO}_{2}$ ratio was calculated based on the current partial arterial oxygen pressure and the inspired oxygen of approximately $27 \%(0.27)$ because of an application of $99.5 \%$ oxygen (10 liter/minute) via nasal insufflation. A tracheobronchial lavage was performed on horse 1, and a cytological evaluation and a gram stain were carried out. Due to the severity of the respiratory distress an endoscopic examination of the upper and lower airways was not performed. A lateral thoracic radiograph of horse 3 was taken at admission and 11 days after treatment initiation at the Department of Large Animal Surgery.

All cases were treated continuously with oxygen (99.5\%, 10 liter/minute) via nasal insufflation. Furthermore, in horses 1 and 2, a supportive therapy with ceftiofur $(2.2 \mathrm{mg} / \mathrm{kg} \mathrm{BW}$, iv), metamizole (20 mg/kg BW, iv), clenbuterol hydrochloride $(0.8$ $\mu \mathrm{g} / \mathrm{kg} \mathrm{BW}, \mathrm{IV})$ twice daily, and gentamicin sulphate $(6.6 \mathrm{mg} / \mathrm{kg}$ $B W$, iv) and vitamin C (5 g, iv) once daily was performed. Additionally, a short-acting corticosteroid (dexamethasone21 -isonicotinate, $0.05 \mathrm{mg} / \mathrm{kg} \mathrm{BW}$, iv) was administered twice in both horses. In addition, horse 1 was inhaled with corticosteroids (budenosid $2 \mathrm{ml}, \mathrm{q} 12 \mathrm{~h}$ ), bronchodilators (salbutamol sulphate, $0.5 \mathrm{ml}, \mathrm{q} 12 \mathrm{~h}$ ) and isotonic saline (5 ml, q6h) daily. In contrast, horse 3 received nasal oxygen insufflation and a three-fold dose of clenbuterol hydrochloride $(2.4 \mu \mathrm{g} / \mathrm{kg}$ BW, iv) twice daily for 6 days, followed by a double dose given orally $(1.6 \mu \mathrm{g} / \mathrm{kg} \mathrm{BW})$ for the next 6 days as well as oral acetylcysteine (4 mg/kg BW) twice daily for 14 days.

\section{Results}

At admission, the clinical findings, as demonstrated in Table 1, showed a depression, tachycardia, tachypnea and cyanosis. No signs of heart failure or hydration abnormalities could be noted. At rest, the patients showed signs of moderate to seve- 
Table 1 General physical examination of three adult horses with ARDS-like signs at admission (ICS: intercostal space). Klinische Untersuchungsbefunde von drei erwachsenen Pferden mit ARDS-ähnlichen Symptomen zur Aufnahme (ICS: Interkostalraum).

\begin{tabular}{|c|c|c|c|}
\hline & Horse 1 & Horse 2 & Horse 3 \\
\hline General attitude & depressed & depressed & normal \\
\hline Heart rate (beats/minute) & 60 & 76 & 86 \\
\hline $\begin{array}{l}\text { Respiratory rate } \\
\text { (breaths/minute) }\end{array}$ & 50 & 54 & 64 \\
\hline Body temperature $\left({ }^{\circ} \mathrm{C}\right)$ & 39.5 & 38.6 & 38.2 \\
\hline Heart sounds & normal & normal & normal \\
\hline Hydration & normal & normal & normal \\
\hline Mucous membranes & red, cyanotic & cyanotic & red, cyanotic \\
\hline Submandibular lymph nodes & normal & normal & normal \\
\hline Nasal discharge & serous & none & none \\
\hline Dyspnea & moderate & severe & severe \\
\hline Cough & occasional, dry & occasional, dry & none \\
\hline Respiratory sounds & $\begin{array}{c}\text { crackles and } \\
\text { wheezes }\end{array}$ & $\begin{array}{c}\text { crackles and } \\
\text { wheezes }\end{array}$ & $\begin{array}{c}\text { crackles and } \\
\text { wheezes }\end{array}$ \\
\hline $\begin{array}{l}\text { Caudoventral lung border } \\
\text { (midthorax) }\end{array}$ & 14. ICS & 14. ICS & 13. ICS \\
\hline
\end{tabular}

re respiratory distress. Horse 1 had mild bilateral serous nasal discharge and horses 1 and 2 had acute onsets of dry cough. All three cases had increased respiratory sounds, especially intensified wheezes and crackles on expiration. The clinicopathologic findings are represented in table 2. Horses 1 and 2 showed a neutrophilia, an elevated LDH and serum lactate. Horse 3 had a leukocytosis, a slightly elevated LDH and a normal serum lactate. The arterial blood gas analysis demonstrated a severe hypoxemia and hypercapnia in all three horses (Table 3). In horses 1 and 2 the $\mathrm{PaO}_{2} / \mathrm{FIO}_{2}$ ratio was $<200$ $\mathrm{mm} \mathrm{Hg}$ and in horse 3 the ratio was $200.4 \mathrm{~mm} \mathrm{Hg}$.

Table 2 Hematological and serum clinical chemistry findings (Clin. chem.) of venous blood of three adult horses with ARDSlike signs at admission (PCV: packed cell volume).

Hämatologische (Erythron, Leukon) und klinisch-chemische Befunde (Clin chem.) im venösen Blut von drei erwachsenen Pferden mit ARDS-ähnlichen Symptomen zur Aufnahme (PCV: Hämatokrit).

\begin{tabular}{|l|l|c|c|c|c|}
\hline Parameter & Normal values & Horse 1 & Horse 2 & Horse 3 \\
\hline \multirow{3}{*}{ Erythron } & PCV I/l & $0.32-0.48$ & 0.38 & 0.40 & 0.36 \\
\cline { 2 - 6 } & Hemoglobin mmol/L & $6.8-11.8$ & 9.5 & 9.2 & 7.9 \\
\cline { 2 - 6 } & Erythrocytes T/L & $6,8-12.9$ & 9.0 & 8.3 & 7.6 \\
\hline \multirow{5}{*}{ Leukon } & Leukocytes G/L & $5.4-10.0$ & 10.7 & 10.6 & 15.1 \\
\cline { 2 - 6 } & Basophils G/L (\%) & $0-0.3(0-4)$ & 0 & $0.1(1)$ & $0.1(1)$ \\
\cline { 2 - 6 } & Eosinophils G/L (\%) & $0-1(0-5)$ & 0 & 0 & $0.4(3)$ \\
\cline { 2 - 6 } & Bands G/L (\%) & $0-0.1(0-2)$ & 0 & 0 & 0 \\
\cline { 2 - 6 } & Neutrophils G/L (\%) & $2.3-8.6(22-72)$ & $9.4(88)$ & $8.7(82)$ & $10.3(68)$ \\
\cline { 2 - 6 } & Lymphocytes G/L (\%) & $1.5-7.7(17-68)$ & $1.2(11)$ & $1.0(9)$ & $3.2(21)$ \\
\cline { 2 - 6 } & Monocytes G/L (\%) & $0-1(0-7)$ & $0.1(1)$ & $0.8(8)$ & $1.1(7)$ \\
\hline Clin. chem. & Total protein g/L & $52-77$ & 67 & 76 & 70 \\
\cline { 2 - 6 } & Albumin g/L & $26-37$ & 35 & 32 & 24 \\
\cline { 2 - 6 } & Urea nitrogen mmol/L & $3.3-6.7$ & 4.5 & 5.8 & 3.2 \\
\cline { 2 - 6 } & Creatinine $\mu \mathrm{mol} / \mathrm{L}$ & $106-159$ & 122 & 106 & 77 \\
\cline { 2 - 6 } & CPK U/L & $92-307$ & 197 & 137 & 110 \\
\cline { 2 - 6 } & AST U/L & $153-411$ & 324 & 310 & 178 \\
\cline { 2 - 6 } & LDH U/L & $162-412$ & 1010 & 1810 & 824 \\
\cline { 2 - 6 } & Lactate mmol/L & $1.1-1.7$ & 2.1 & 2.7 & 1.4 \\
\hline
\end{tabular}

In horse 3, the lateral thoracic radiographs showed diffuse ground-glass opacity as well as interstitial and alveolar infiltrates. A diffuse bronchiectasis could also be seen. The cardiac silhovette was normal (Fig. 1).

Despite oxygen supplementation, the respiratory status deteriorated in horses 1 and 2. After the administration of corticosteroids, the respiratory rate and breathing effort increased. These horses had an extended head and neck, nostril
Table 3 Arterial blood gas analyses of three adult horses with ARDS-like signs at admission. The inspired oxygen concentration of $27 \%(0.27)$ resulted from nasal inhalation of $99.5 \%$ oxygen (10 liter/minute) was used for the calculation of $\mathrm{PaO}_{2} / \mathrm{FIO}_{2}$ ratio.

Arterielle Blutgasanalyse von drei erwachsenen Pferden mit ARDS-ähnlichen Symptomen zur Aufnahme. Die Berechnung des $\mathrm{PaO}_{2} / \mathrm{FIO}_{2}$-Quotienten erfolgte mit einer Saverstoffkonzentration der Atemluft von $27 \%(0,27)$ resultierend aus der transnasalen Inhalation mit 99,5\%igem Saverstoff (10 Liter/Minute).

\begin{tabular}{|l|c|c|c|c|}
\hline Parameter & Normal values & Horse 1 & Horse 2 & Horse 3 \\
\hline $\mathrm{pH}$ & $7.38-7.44$ & 7.39 & 7.30 & 7.34 \\
\hline $\mathrm{pCO}_{2} \mathrm{kPa}$ & $4.80-6.10$ & 6.77 & 8.97 & 6.83 \\
\hline $\mathrm{pO}_{2} \mathrm{kPa}$ & $12.00-13.80$ & 6.97 & 4.62 & 7.21 \\
\hline $\mathrm{sO}_{2} \%$ & $>98.0$ & 87.9 & 53.9 & 84.2 \\
\hline $\mathrm{PaO} 2 / \mathrm{FIO} 2$ ratio $\mathrm{mm} \mathrm{Hg}$ & & 193.7 & 128.2 & 200.4 \\
\hline
\end{tabular}

flaring and later open-mouth breathing (Fig. 2). Horse 1 died 72 hours after admission and horse 2 died 26 hours after admission. Necropsy findings performed at the Institute of Veterinary Pathology revealed a severe alveolar damage with pulmonary edema and diffuse accumulation of alveolar

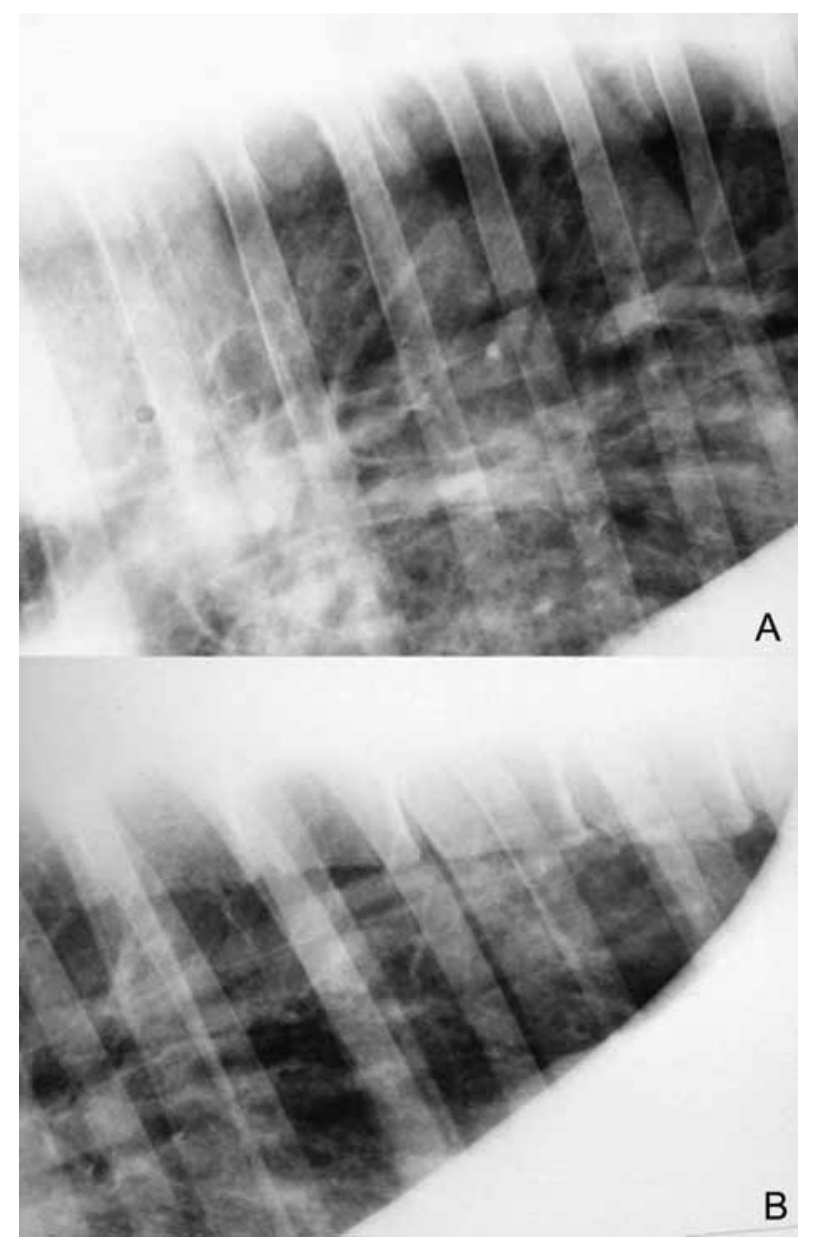

Fig 1 Lateral thoracic radiograph of horse 3 with interstitial and alveolar pulmonary infiltrates and bronchiectasis at admission (Department of Large Animal Surgery, University Leipzig).

Laterale Röntgenaufnahme des Thorax von Pferd 3 mit interstitiellen und alveolären pulmonalen Verschattungen und Bronchiektasien zur Aufnahme.

hyaline membranes including catarrhal pneumonia and interstitial fibrosis without detectable basic causes in both cases. 
In contrast to these horses, horse 3 which was not treated with corticosteroids showed a continuous improvement of the respiratory signs. Oxygen supplementation was continued for two days. The respiratory rate returned to normal values within 8 days and the blood gas analysis returned to normal values within 10 days. Recheck radiographs of the chest revealed an improvement of the lung. The horse was discharged from the clinic 14 days after admission. Three days after discharge, the signs of respiratory distress recurred spontaneously. On recommendation, the owner changed environment. The horse was kept in a low-dust stable with free access to pasture and received good-quality hay and oat. Additionally, he repeated treatment on the horse with clenbuterol hydrochloride $(2.4 \mu \mathrm{g} / \mathrm{kg}$ BW orally twice daily) for 14 days. The horse improved sufficiently to be used for low intensity exercise three months later.

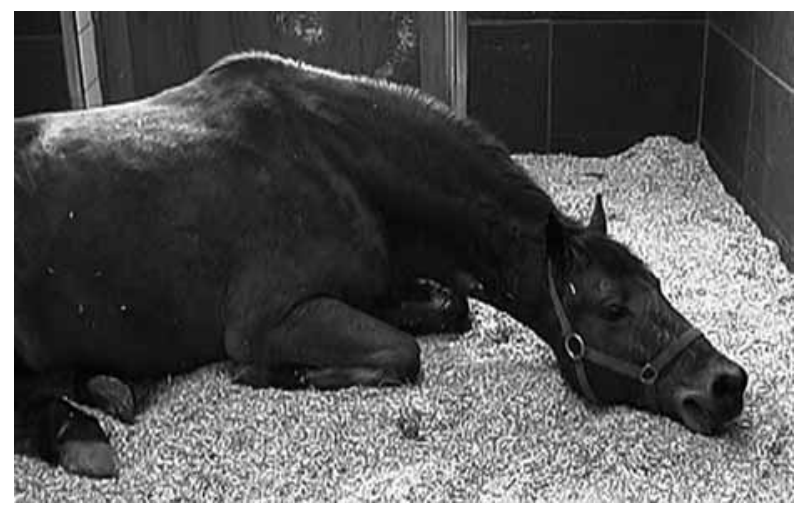

Fig 2 Horse 2 in sternal recumbency with severe respiratory distress, 20 hours after admission.

Pferd 2 in Brust-Bauchlage mit Symptomen einer hochgradigen Dyspnoe, 20 Stunden nach der Aufnahme.

\section{Discussion}

Clinical criteria used in humans to distinguish ARDS from other acute pulmonary injuries including acute onset of severe respiratory distress, severe blood gas disturbances, $\mathrm{PaO}_{2} / \mathrm{FIO}_{2}$ ratio $<200 \mathrm{~mm} \mathrm{Hg}$, interstitial and alveolar pulmonary infiltrates on thoracic radiographs, and normal cardiac function were helpful to diagnose ARDS in these three horses (Bernard et al. 1994). The histopathological examination included severe alveolar damage with accumulation of alveolar hyaline membranes and fibrosis in two cases. The clinical signs and findings on necropsy are similar to those of ARDS described in humans (Corrin 2000, Wilkens and Seahorn 2004). The clinical signs of horse 3 appeared to be ARDS-like disease as a result of a severe allergic small airway inflammation after repeated exposure to mouldy hay. This reaction could be compared to allergic alveolitis or bronchiolitis similar to those seen in acute onsets of recurrent airway obstructions (RAO) (Leguillette 2003). In humans, the most common predisposing conditions to developing ARDS are indirect insults such as severe disorders of other organs, systemic inflammatory response, severe trauma or direct pulmonary infection, aspiration of gastric contents, toxic inhalation, burns or upper airway obstruction (Bernard et al. 1994, Varon and Wenker 1997). In horses, the onset of respiratory distress has been described secondary to viral disease, chemical toxicants, shock, heatstroke, DIC and septicemia (Lakritz et al. 1993).
The basic abnormality in ARDS is the disruption of the normal alveolar-capillary barrier (Corrin 2000). So far, no sensitive or specific markers have been recognized to determine pulmonary epithelial or capillary endothelial injuries (Varon and Wenker 1997). Changes in specific clinicopathologic parameters can be applied as good prognostic indicators of the development of life-threatening pulmonary complications. A partial arterial pressure of oxygen $<8.7 \mathrm{kPa}$ and the presence of a non-cardiogenic pulmonary edema, an oxygen saturation $<90 \%$, serum lactate $>2.3 \mathrm{mmol} / \mathrm{l}$, a decreased total serum protein, especially transferrin as well as alterations in surfactant compositions are possible changes to determine lung injuries (Arif et al. 2002, Cheng et al. 2003, Petty 1985).

The American-European Consensus Conference defined ARDS with a ratio of arterial oxygenation to the fraction of inspired oxygen $\left(\mathrm{PaO}_{2} / \mathrm{FIO}_{2}\right.$ ratio) $<200 \mathrm{~mm} \mathrm{Hg}$ (Bernard et al. 1994). Human clinical criteria for identification of ARDS may be also helpful in diagnosis of this disease in dogs (Parent et al. 1996). The diagnosis of ARDS in the first two cases was based on clinical signs such as severe dyspnea, hypoxemia and a $\mathrm{PaO}_{2} / \mathrm{FlO}_{2}$ ratio $<200 \mathrm{~mm} \mathrm{Hg}$. As a result of the $\mathrm{PaO}_{2} / \mathrm{FIO}_{2}$ ratio of approximately $200 \mathrm{~mm} \mathrm{Hg}$ and the findings on the chest radiographs in horse 3 , an ARDS-like syndrome was diagnosed. The cytological evaluation of the tracheobronchial lavage did not allow a diagnosis, but bacterial etiology could be excluded. The possible causes of development of ARDS in the first two cases remained unknown, although aerogen absorption of potentially noxious substances, a viral infection or the treatment with different antibiotics could have played a role. Thoracic radiographs were helpful in the early recognition of pulmonary alterations. Therefore, routine thoracic radiographs are reasonable options for monitoring the progression of disease and success of therapy (Desai 2002).

The prognosis of patients with ARDS depends on the predisposing causes and remains guarded. A multiorgan failure is the most frequent cause of death (Petty 1985, Varon and Wenker 1997). In humans, the severity of clinical signs, a $\mathrm{PaO}_{2} / \mathrm{FIO}_{2}$ ratio $<150 \mathrm{~mm} \mathrm{Hg}$, decreased oxygen saturation, a decreased $\mathrm{pH}$, and an increased serum lactate are prognostically important (Brun-Buisson et al. 2004, Cheng et al. 2003, Petty 1985). Two of these horses with ARDS presented here died as a result of the disease. Both horses showed the most marked clinical signs. Additional to decreased $\mathrm{PaO}_{2} / \mathrm{FIO}_{2}$ ratio and increased serum lactate, $\mathrm{LDH}$ activity was markedly elevated. Serum LDH activity is an indicator of tissue injury, and it may be increased in several interstitial pulmonary diseases of human beings (Matusiewicz et al. 1993, McFadden and Oliphant 1991). Therefore, both serum lactate and LDH could be valuable prognostic indicators also in horses with ARDS. The findings of the arterial blood gas analysis of these three horses were not specific enough to determine a prognosis.

In ARDS, affected horses are always emergency patients and require immediate treatment (Varon and Wenker 1997). A cornerstone of therapy is the continuous supplementation of oxygen. The goal is to achieve an oxygen saturation of $90 \%$ (Slutsky 1993). In the early stage of the disease, the human patient is usually able to meet the oxygen requirements via open respirators (nasal, oronasal face masks). The need for an 
intubation and artificial respiration exists with diffuse pulmonary damage. A crucial parameter seems to be the PEEP (positive end-expiratory pressure), which has a positive effect on oxygenation and the decrease of pulmonary edema (Kopp et al. 2002, Springer and Stevens 1979). Rose et al. (1983) examined the effect of intranasal administration of oxygen at a flow rate of 10 liters per minute for 10 and 40 minutes in premature foals and found a significant increases on $\mathrm{PaO}_{2}$ without effect of duration of administration on blood gas values. In our studie, the nasal insufflation of oxygen at a dose of at least 10 liters per minute was also considered a necessary treatment. The high loss of oxygen to the environment is a disadvantage. The inhalation via a breathing mask would be more favorable; however, horses with severe dyspnea do not tolerate these well. Anxiety, restlessness and an intensification of respiratory distress are the result of the diminished inspiratory volume capacity. The application of oxygen to affected horses via intubation is also possible. Intubation and artificial respiration with a heart-lung machine would be optimal; however, this application would only be feasible under general anesthesia and, therefore, remains limited. For this reason, the nasal or transtracheal oxygen supply or an inhalation mask remain the therapeutic choices in horses with ARDS.

The prophylactic use of heparin and/or antithrombin III for uncontrolled activation of coagulation has already been clinically established (Welty-Wolf et al. 2002). In horses with coagulopathies low molecular weight heparin in a dosage of $50 \mathrm{IU} / \mathrm{kg}$ BW daily is recommended for prophylaxis of coagulation abnormalities (Feige et al. 2003). Therefore, low molecular weight heparin can be used in the initial stages of ARDS to improve the success of treatment.

Vitamin $\mathrm{E}$ and vitamin $\mathrm{C}$ in high doses are considered favourable as free oxygen radical scavengers (Gadek et al. 1999). Up to $5 \mathrm{~g}$ of vitamin C daily and 1000-1500 mg of vitamin E per $500 \mathrm{~kg}$ BW every other day can be given to horses with ARDS. N-acetylcystein is an oxygen radical scavenger that is abel to ameliorate inflammatory lung injury, since oxyen radicals derived from activated xanthine oxidase or neutrophil promote proinflammatory mechanisms and play a major role in ARDS (Bernard et al. 1997, Fink 2002). Spies et al. (1994) found that intravenous $\mathrm{N}$-acetylcysteine at an initial dose of $150 \mathrm{mg} / \mathrm{kg}$ BW intravenously, followed by a continuous infusion of $12.5 \mathrm{mg} / \mathrm{h}$ resulted in an improvement of the survival rate in humans with ARDS. Due to the ample therapeutic range of $\mathrm{N}$-acetylcysteine, the aforementioned dose is also considered appropriate in horses.

The transbronchial application of surfactant is already a component of therapy in clinical neonatalogy to maintain surface tension of the alveoli (Lewis and Veldhuizen 2003). Dosages of 300-500 mg of bovine surfactant (Alveofact ${ }^{\circledR}$ ) per kg BW led to an improvement of the surfactant composition and the gas exchange in adult humans with ARDS (Walmrath et al. 2002). In a study of Freeman et al. (1989), surfactant treatment of equine neonates with ARDS-like clinical signs was effective in the short term, improving oxygenation, lung compliance, and the radiographic appearance of the lung. But the effect was generally short lived ( $<8$ hours), and the treatment needs to be repeated frequently. Due to the high costs, the routine employment of transbronchial surfactant in adult horses is clinically not applicable.
For some time the application of nitric oxide (NO) as an endothelial and bronchial relaxing factor via the artificial respiration system was successful in the treatment of ARDS (Groeneveld 2003, Tasaka et al. 2002). Inhalation of NO has been tried to help open up nonventilated lung regions and to promote blood flow therein (Lowson 2002). Hence, inhaled $\mathrm{NO}$ would be optimal for improving perfusion to ventilation matching in the lung, provided the smooth muscle cells of bronchi and vessels are still responsive to exogenous NO (Groeneveld 2003). Nitric oxide concentrations as small as $10 \mathrm{ppm}$ had a positive effect on the pulmonary gas exchange (lowering of the pulmonary resistance) and led to an improvement of the systemic oxygen supply. Similarly, inhaled bronchodilators produced an improvement of oxygenation, an increased compliance and a reduced resistance of the lung (Wright et al. 1994). Treatment with clenbuterol in a dosage of $2.4 \mu \mathrm{g} / \mathrm{kg}$ BW twice daily given intravenously is considered a very effective method to bronchodilate affected horses and leads to an improvement of the respiratory effort, as observed in horse 3 (Erichsen et al. 1994).

Pulmonary edema in patients with ARDS can be successfully decreased with a reduction of the hydrostatic pressure by a negative liquid balance (e.g. use of diuretics) (Groeneveld 2003, Tasaka et al. 2002). In animal experiments, Reising et al. (1999) obtained an improvement in oxygenation, decreased pulmonary shunts and decreased severity of the clinical signs after continuous infusion of diuretics. However, this positive therapeutic effect during the exudative stage of ARDS is limited by two factors: a drastic fluid restriction which favors the development of acute renal failure, and infusion therapy which is necessary to improve the oxygen distribution and supply of the peripheral organs in septic patients.

Due to the fact that ARDS represents an acute inflammatory process, there is a possibility of inhibiting the plasmatic inflammatory cascades by means of anti-inflammatory drugs. Corticosteroid treatment of ARDS has been the most controversial clinical issues (Thompson 2002, Wilkens and Seahorn 2004). In the early stages of the disease, steroids in high dosages led to variable success rates in contrast to an increased incidence of mortality in humans. Only in the fibroproliferative stage do glucocorticoids seem to cause an improvement in the prognosis (Groeneveld 2003, Tasaka et al. 2002). Although corticosteroids have been used in conditions such as bronchiectasis and recurrent airway obstruction ("heaves") in horses to reduce airway inflammation and decrease mucus production, severely affected horses have failed to respond to this therapy (Lavoie et al. 2004). The question of if and when corticosteroids will improve the prognosis of ARDS remains open also in veterinary medicine and more detailed studies are required. In this study, dexamethasone led to a deterioration of respiratory distress and tachypnea. The cause is unknown and prospective controlled studies are highly indicated. The suppression of the nitric oxide synthetase in a short period of time followed by a decreasing bronchodilatory and vasodilatory effect of $\mathrm{NO}$ could be the cause of this event (Kaever and Resch 2001). Therefore, the application of glucocorticoids in the early stages of ARDS is also in horses not indicated, perhaps even contraindicated (Kopp et al. 2002). As previously reported, NSAIDs are ineffective in treating the inflammation in ARDS specifically (Groeneveld 2003). 
Finally, the most important aspect of treatment of horses with pulmonary injuries is to guarantee optimal environmental conditions (low-dust stables or pasture), and to avoid exposure to pulmonary allergens and toxins (Leguillette 2003, McGorum et al. 1998).

In conclusion, ARDS is a life-threatening disease in horses characterized by an acute onset of respiratory failure due to pulmonary edema. Diagnosing this disease in horses is based on severe clinical signs of respiratory distress and therapyresistant hypoxemia with a $\mathrm{PaO}_{2} / \mathrm{FlO}_{2}$ ratio $<200 \mathrm{~mm} \mathrm{Hg}$. Specific clinicopathological data such as serum lactate and $\mathrm{LDH}$ aid in determining the prognosis. Thoracic radiographs are helpful in detecting pulmonary edema and observing the success of treatment. Based on the risk factors, therapy of ARDS is largely supportive. The most important supportive measure is the supplementation of oxygen. The application of oxygen via nasal tube is the most practical method. The use of clenbuterol intravenously in a dosage of $2.4 \mu \mathrm{g} / \mathrm{kg} \mathrm{BW}$ twice daily is an effective possibility to facilitate respiratory effort. The administration of glucocorticoids in the early stage of ARDS seems to deteriorate respiratory distress in horses.

\section{Manufacturer's addresses}

1 "Technikon H-1ETM “, Bayer, München, Germany

2 Automatic Analyzer "Hitachi 704", Boehringer, Mannheim, Germany

3 "ABL 510", Radiometer, Kopenhagen, Denmark

\section{Literature}

Arif S. K., Verheij J., Groeneveld A. B. J. and Raijmakers P. G. H. M. (2002): Hypoproteinemia as a marker of acute respiratory distress syndrome in critically ill patients with pulmonary edema. Intensive Care Med 28, 310-317

Ashbaugh D. G., Bigelow D. B., Petty T. L. and Levine B. E. (1967): Acute respiratory distress in adults. Lancet ii, 319-323

Bernard G. R., Artigas A., Brigham K. L., Carlet J., Falke K., Hudson L., Lamy M., Legall J. R., Morris A., Spragg R. and the Consensus Committee (1994): The American-European consensus conference on ARDS: Definitions, mechanisms, relevant outcomes, and clinical trial coordination. Am J Respir Crit Care Med 149, 818-824

Bernard G. R., Wheeler A. P., Arons M. M., Morris P. E., Paz H. L., Russell J. A. and Whright P. E. (1997): A trial of antioxidants Nacetylcysteine and procysteine in ARDS. Chest 112, 164-172

Brun-Buisson C., Minelli C., Bertolini G., Brazzi L., Pimentel J., Lewandowski K., Bion J., Romand J. A., Villar J., Thorsteinsson A., Damas P., Armaganidis A. and Lemaire F. (2004): Epidemiology and outcome of acute lung injury in European intensive care units. Intensive Care Med 30, 51-61

Cheng I. W., Ware L. B., Greene K. E., Nuckton T. J., Eisner M. D. and Matthay M. A. (2003): Prognostic value of surfactant proteins $A$ and $D$ in patients with acute lung injury. Crit Care Med 31, 2027

Corrin B. (2000): Diffuse alveolar damage, the pathological basis of the adult respiratory distress syndrome. In: Corrin B (ed): Pathology of the lungs. Churchill Livingstone, London, 121-135

Desai S. R. (2002): Acute respiratory distress syndrome: Imaging of the injured lung. Clin Radiol 57, 8-17

Erichsen D. F., Aviad A. D., Schultz R. H. and Kennedy T. J. (1994): Clinical efficacy and safety of clenbuterol $\mathrm{HCl}$ when administered to effect in horses with chronic obstructive pulmonary disease (COPD). Equine Vet J 26, 331-336
Feige K., Schwarzwald C. C. and Bombeli T. (2003): Comparison of unfractioned and low molecular weight heparin for prophylaxis of coagulopathies in 52 horses with colic: a randomised doubleblind clinical trial. Equine Vet J 35, 506-513

Fink M. P. (2002): Role of reactive oxygen and nitrogen species in acute respiratory distress syndrome. Curr Opin Crit Care 8, 6-11

Freeman K. P., Cline J. M., Simmons R., Wilkins P., Cudd T. A. and Perry B. J. (1989): Recognition of bronchopulmonary dysplasia in newborn foals. Equine Vet J 21, 292-296

Gadek J. E., DeMichele S. J., Karlstad M. D., Pacht E. R., Donahoe M., Albertson T. E., Van Hoozen C., Wennberg A. K., Nelson J. L. and Noursalehi M. (1999): Effect of enteral feeding with icosapentaenoic acid, gamma-linolenic acid, and antioxidants in patients with acute respiratory distress syndrome. Crit Care Med 27, 1409-1420

Groeneveld A. B. J. (2003): Vascular pharmacology of acute lung injury and acute respiratory distress syndrome. Vasc Pharmac 39, 247-256

Kaever V. and Resch K. (2001): Antiphlogistika und Immuntherapeutika. In: Forth W, Henschler D and Rummel W (eds): Allgemeine und spezielle Pharmakologie und Toxikologie. Urban \& Fischer, München and Jena, 393-427

Kelly D. F., Newsholme S. J., Baker J. R. and Ricketts S. W. (1995): Diffuse alveolar damage in the horse. Equine Vet J 27, 76-78

Kopp R., Kuhlen R., Max M. and Rossaint R. (2002): Evidence-based medicine in the therapy of the acute respiratory distress syndrome. Intensive Care Med 28, 244-255

Lakritz J., Wilson D., Berry C. R., Schrenzel M. D., Carlson G. P. and Madigan J. E. (1993): Bronchointerstitial pneumonia and respiratory distress in young horses: clinical, clinicopathologic, radiographic, and pathological findings in 23 cases (1984-1989). J Vet Intern Med 7, 277-289

Lang J. D., McArdle P. J., O'Reilly P. J. and Matalon S. (2002): Oxidantantioxidant balance in acute lung injury. Chest 122, 314S-320S

Lavoie J. P., Dalle S., Breton L. and Helie P. (2004): Bronchiectasis in three adult horses with heaves. J Vet Intern Med 18, 757-760

Lazarov S., Nokolov R. and lanev E. (2001): Adult respiratory distress syndrome - etiology and pathogenesis. Vutr Boles 33, 14-27

Leguillette R. (2003): Recurrent airway obstruction - heaves. Vet Clin North Am Equine Pract 19, 63-86

Lewis J. F. and Veldhuizen R. (2003): The role of exogenous surfactant in the treatment of acute lung injury. Annu Rev Physiol 65, 613-642

Lowson S. M. (2002): Inhalted alternatives to nitric oxide. Anesthesiology 96, 1504-1513

Matusiewicz S. P., Williamson I. L., Sime P. J., Brown P. H., Wenham R. P., Crompton G. K. and Greening A. P. (1993): Plasma lactate dehydrogenase: a marker of disease activity in cryptogenic fibrosing alveolitis and extrinsic allergic alveolitis? Eur Respir J 6, 1282-1286

McFadden R. G. and Oliphant L. D. (1991): Serum lactate dehydrogenase in interstitial lung disease. Chest 100, 1182

McGorum B. C., Ellison J. and Cullen R. T. (1998): Total and respirable airborne dust Endotoxin concentrations in three equine management systems. Equine Vet J 30, 430-434

Parent C., King L. G., van Winkle T. J. and Walker L. M. (1996): Respiratory function and treatment in dogs with acute respiratory distress syndrome: 19 cases (1985-1993). J Am Vet Med Assoc 208, 1428-1433

Petty T. L. (1985): Indicators of risk, course and prognosis in adult respiratory distress syndrome (ARDS). Am Rev Resp Dis 132, 471

Reising C. A., Chendrasekhar A., Wall P. L., Paradise N. F., Timberlake G. A. and Moorman D. W. (1999): Continuous dose furosemide as a therapeutic approach to acute respiratory distress syndrome (ARDS). J Surg Res 82, 56-60

Riemensberger P. C. (2002): Neonatal respiratory failure. Curr Opin Pediatr 14, 315-321

Rinaldo J. E. and Christman J. W. (1998): Acute respiratory distress syndrome: Pathogenesis. In: Fishman A. P., J. A. Elias and J. A. Fishman (eds): Fishman's pulmonary diseases and disorders. McGraw-Hill, New York, 2537-2548 
Rose R. J., Hodgson D. R., Leadon D. P. and Rossdale P. D. (1983): Effect of intranasal oxygen administration on arterial blood gas and acid base parameters in spontaneously delivered, term induced and induced premature foals. Res Vet Sci 34, 159-162

Slutsky A. S. (1993): ACCP Consensus Conference: Mechanical ventilation. Chest 104, 1833-1859

Spies C. D., Reinhart K., Witt I., Meier-Hellmann A., Hannemann L., Bredle D. L. and Schaffartzik W. (1994): Influence of N-acetylcysteine on indirect indicators of tissue oxygenation in septic shock patients: Results from a prospective, randomized, double-blind study. Crit Care Med 22, 1738-1746

Springer R. R. and Stevens P. M. (1979): The influence of PEEP on survival of patients in respiratory failure. Am J Med 66, 196-202

Tasaka S., Hasegawa N. and Ishizaka A. (2002): Pharmacology of acute lung injury. Pulm Pharmac Therap 15, 83-95

Thompson B. P. (2002): Glucocorticoids and acute lung injury. Crit Care Med 31, 253-257

Turk J. R., Brown C. M. and Johnson G. C. (1981): Diffuse alveolar damage with fibrosing alveolitis in a horse. Vet Pathol 18, 560562

Udobi K. F., Childs E. and Touijer K. (2003): Acute respiratory distress syndrome. Am Fam Physician 67, 315-322

Varon J. and Wenker O. C. (1997): The acute respiratory distress syndrome: Myths and controversies. Internet J Emergency and Intensive Care Med 1, 1-10

Walmrath D., Grimminger F., Pappert D., Knothe C., Obertacke U., Benzing A., Gunther A., Schmehl T., Leuchte H. and Seeger W. (2002): Bronchoscopic administration of bovine natural surfactant in ARDS and septic shock: Impact on gas exchange and haemodynamics. Eur Respir J 19, 805-810
Weiland J. E., Davis W. B., Holter J. F., Mohammed J. R., Dorinsky P. M. and Gadek J. E. (1986): Lung neutrophils in the adult respiratory distress syndrome - clinical and pythological significance. Am J Respir Crit Care Med 162, 1783-1788

Welty-Wolf K. E., Carraway M. S., Ortel T. L. and Piantadosi C. A. (2002): Coagulation and inflammation in acute lung injury. Thromb Haemost 88, 17-25

Wilkens P. A. and Seahorn T. (2004): Acute respiratory distress syndrome. Vet Clin North Am Equine Pract 20, 253-273

Wright P. E., Carmichael L. C. and Bernard G. R. (1994): Effect of bronchodilators on lung mechanics in the acute respiratory distress syndrome (ARDS). Chest 106, 1517-1523

Dr. Astrid Grosche

Universität Leipzig

Medizinische Tierklinik

An den Tierkliniken 11

04103 Leipzig

grosche@rz.uni-leipzig.de

\section{Pferdeheilkunde Curriculum}

\section{Kaufuntersuchung}

Hartmut Gerhards, Arthur Grabner und Dietrich Plewa 14.-15. Januar 2006, Humbold Universität Berlin

Die Rollenverteilung bei der Kaufuntersuchung: Auftraggeber, Verkäufer, Käufer, Tierarzł Aufklärung und Dokumentation, Vorbedingungen für die Kaufuntersuchung

Erklärung des Verkäufers und Auftrag

Umfang und Ablauf der klinischen Untersuchung

Röntgenuntersuchung, Die radiologische Beurteilung des Pferdes

Zur Rolle des Röntgenleitfadens

Besondere ergänzende Untersuchungen

Bewertung der Ergebnisse, der Pferdeheilkunde Formularvertrag

Allgemeine Vertragsbedingungen, Haftung und Honorierung

Vertragsmäßige Verkürzung der Gewährsfrist

Die Kaufuntersuchung als Grundlage von Rechtsstreitigkeiten Haftung gegenüber Dritten

Entwicklung der Rechtsprechung unter dem neuen Schuldrecht

\section{www.pferdeheilkunde.de}

